\title{
An Introduction to the Special Issue on Ecological Sites
}

\section{By Brandon T. Bestelmeyer and Joel R. Brown}

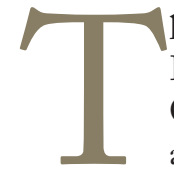

he establishment of the Rangeland Interagency Ecological Site Manual by the Natural Resources Conservation Service (NRCS), Forest Service, and the Bureau of Land Management heralds a new era of rangeland management in the United States (http://www.fs.fed.us/biology/soil/Signed_RIESM_2010. pdf). The manual promises to establish a land stratification system and approaches for describing ecosystem structures, functions, and dynamics in the form of ecological site descriptions, such that they can be applied to all rangelands, no matter their jurisdiction or ownership. The common basis for decision-making will lead to improved coordination and more consistent, transparent, and useful application of science concepts in rangeland management. NRCS has had primary responsibility for the development of ecological site descriptions in the past. This responsibility will be now be shared by all three agencies. At this juncture, we summarize in this special issue the state of the art in the development of ecological site descriptions, recognizing that this art will evolve over the coming decades.

An ecological site has been defined as "a distinctive kind of land with specific physical characteristics that differs from other kinds of land in its ability to produce a distinctive kind and amount of vegetation, and in its ability to respond to management actions and natural disturbances" (draft Interagency Ecological Site Handbook for Rangelands). Another, simpler definition is that they divide landscapes into basic units for study, evaluation, and management. ${ }^{1}$

Why should we concern ourselves with dividing landscapes into basic units? It is because this activity allows us to recognize and communicate important and repeatable differences in vegetation, soils, and ecological processes occurring within different parts of a landscape (Brown, this issue). By important, we mean that the differences are strong enough to influence the success or failure of a management action or affect the types of ecosystem services or benefits that are provided by a land area. These differences, in turn, create distinct expectations regarding land health and potential uses. The differences then can be used to adjust management practices and interpretations of monitoring and assessment data. Ecological sites allow us to say that our goals and expectations for land should not be the same everywhere in a landscape, and we can specify with some precision what those different expectations are. This has great benefits for private land owners, public lands users, and government regulators who might otherwise slip into "one-size-fits-all" thinking that has, in the past, led to environmental degradation and conflict.

By repeatable, we mean that landscapes are not an incomprehensible jumble of plants, animals, and soils that respond in unpredictable ways to human influences. There are patterns and organization in their relationships. As the great ecologist Robert MacArthur ${ }^{2}$ wrote, "to do science is to search for repeated patterns, not simply to accumulate facts, and to do the science of geographical ecology is to search for patterns in plant and animal life that can be put on a map." The development of ecological sites clearly requires art, but it is foremost a science. In fact, it is the science of geographical ecology, with a focus on patterns at the levels of landscapes to regions and on attributes and processes that are important to land management.

How should we divide landscapes into ecological sites? That question is addressed primarily in two papers of this special issue, including an introduction to how soils are used to divide and map ecological sites (Duniway et al.) and a general approach to developing and testing ecological site concepts (Moseley et al.). Ecological site development begins with a hierarchical subdivision of land areas according to climate, landforms, and soils. The Major Land Resource Areas (MLRA) and Land Resource Units (LRU) used within the USDA Natural Resources Conservation Service are the broadest levels in this hierarchy. The MLRAs are regional divisions of the United States based on strong differences in climate, physiography, plant geography, and general land uses. They are similar to the divisions in Omernik's "Level III ecoregions" 3 and the "sections" of the National Hierarchy of Ecological Units. ${ }^{4}$ LRUs are subdivisions of MLRAs that distinguish areas of different regional climate and/or geomorphology (similar to "Level IV ecoregions" and "subsections," but often difficult to map 
directly). For example, 8-12-inch and 12-16-inch precipitation zones would be different LRUs of the same MLRA. Soils and landforms are then used to divide the LRU into a set of complementary ecological sites. The rules for dividing soils to ecological sites are often common within an MLRA (e.g., a Loamy upland 8-12-inch ecological site and Loamy upland 12-16-inch ecological site). The Duniway and Moseley papers illustrate how to develop such rules.

Each ecological site produces a "distinctive kind and amount of vegetation" that responds differently to "management actions and natural disturbances." How do we define what kinds and amounts of vegetation can be produced, and how do we describe its dynamic responses to management and natural events? State-and-transition models summarize the changes to vegetation and soils-and their causes - that occur on an ecological site. A paper by Bestelmeyer et al. presents ideas for developing the components of state-and-transition models and a paper by Knapp et al. describes the critical role of local knowledge in model development. The paper by Duniway et al. discusses soil properties and processes that help to define alternative states in many instances.

Most ecological sites and state-and-transition models thus far have been developed in upland grasslands, shrublands, and savannas. Efforts in forests and riparian areas have revealed that ecological site development protocols require distinct concepts and approaches as a consequence of differences in ecosystem organization. Papers by Stringham and Repp (for riparian areas) and Townsend (for forests) discuss these variations.

Finally, how should we link information to and use ecological sites? Whereas ecological sites are classes of a land classification system, ecological site descriptions (ESDs) are reports with associated data that contain the body of information associated with each ecological site. An ESD is the documentation of the characteristics of an ecological site (including its climate, soils, and state-and-transition model) and the interpretation of its properties related to use and management. Gilgert and Zack discuss the linkage of ecosystem services - benefits to society-to the interpretations portion of ESDs with an emphasis on wildlife as examples. Talbot et al. then discuss the current structure of the database systems linking soil characteristics and mapping to ESDs, with an eye toward next steps. Finally, Karl and Herrick illustrate how information in ESDs, spatial data, and other tools can be used to implement management, assessment, and monitoring. This brings us full circle, illustrating the utility of ecological sites as basic units for our interpretation of landscapes.

Although ecological sites as a concept have existed since the early 20th century, systematic science-based approaches to ecological sites have been slow to emerge. That is not to say there has been slow progress in the science underpinning ecological sites. Advances in soil science, plant science, geography, and rangeland, community, and ecosystem ecology have had clear impacts that are illustrated in this special issue. But there is not yet a well-developed, interdisciplinary field of study that unifies concepts toward the development of ecological sites. There are (to our knowledge) no university courses or texts on ecological sites and no university faculty positions dedicated to the study of ecological sites. Federal agency positions that focus primarily on ecological sites only recently have been established. Ecological sites have been an important part of rangeland management for decades, but largely in the background. It is our hope that this special issue helps to bring the science and art of ecological sites to the front and center.

\section{Acknowledgments}

Each of the papers in this special issue has been peer reviewed. We would like to thank the following people for their time and effort in providing peer review and constructive comment on these papers: Eldon Ayers, Mark Brunson, Laura Burkett, Mel George, Kris Havstad, Jason Karl, Curtis Monger, George Peacock, Jeff Printz, Dan Robinett, Nathan Sayre, Tony Svejcar, David Trujillo, Arlene Tugel, and Bruce Wight. Their contributions improved the quality of this issue and are greatly appreciated.

\section{References}

1. US Department of Agriculture-Natural Resources Conservation Service. 2003. National range and pasture handbook. Washington, DC, USA: US Department of Agriculture.

2. MacArthur, R. H. 1972. Geographical ecology: patterns in the distribution of species. New York, NY, USA: Harper and Row. 288 p.

3. Omernik, J. 1987. Ecoregions of the conterminous United States. Annals of the Association of American Geographers 77(1):118-125.

4. Cleland, D. T., P. E. Avers, W. H. McNab, M. E. Jensen, R. G. Bailey, T. King, and W. E. Russell. 1997. National hierarchical framework of ecological units. In M. S. Boyce and A. Haney [EDs.]. Ecosystem management applications for sustainable forest and wildlife resources. New Haven, CT, USA: Yale University Press. p. 181-200.

Authors are Research Ecologist, USDA-Agricultural Research Service Jornada Experimental Range, Las Cruces, NM 88003, USA, bbestelm@nmsu.edu (Bestelmeyer); and Soil Scientist, USDA-Natural Resources Conservation Service, National Soil Survey Center and Jornada Experimental Range, Las Cruces, NM 88003, USA (Brown). 